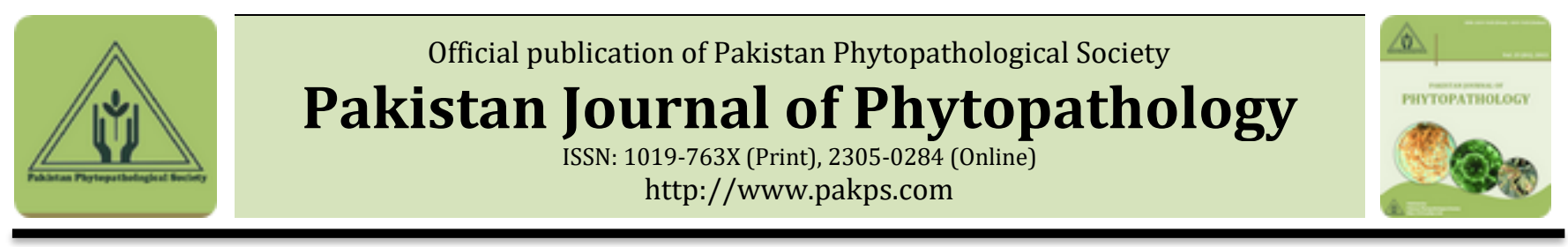

\title{
EPIDEMIOLOGICAL STUDIES OF TOMATO LEAF CURL VIRUS AND WHITEFLY POPULATION AND THEIR MANAGEMENT USING BOTANICALS
}

\author{
a,b,dMirza A. Mehmood, bashida Perveen, bSobia Chohan, ${ }^{c}$ Muhammad Ishtiaq, dMuhammad M. Ahmed, \\ eMuhammad Shaaban, dAneela Younas, fHafsa Umer, bNaila Akram, bMuhammad Abid, bMuhammad Sajid \\ ${ }^{a}$ Department of Plant Pathology, Muhammad Nawaz Shareef University of Agriculture, Multan, Pakistan. \\ ${ }^{\boldsymbol{b}}$ Department of Plant Pathology, Faculty of Agricultural Sciences and Technology, Bahauddin Zakariya University, \\ Multan, Pakistan. \\ c Department of Entomology, Muhammad Nawaz Shareef University of Agriculture, Multan, Pakistan. \\ ${ }^{d}$ College of Plant Science and Technology, Huazhong Agricultural University, Wuhan, China. \\ ${ }^{e}$ College of Resource and Environment, Huazhong Agricultural University, Wuhan, China. \\ f Department of Food Science and Technology, Muhammad Nawaz Shareef University of Agriculture, Multan, Pakistan.
}

\section{A B S T R A C T}

Tomato (Solanum lycopersicum L.) is an important food crop extensively grown all over the world and is susceptible to various abiotic and biotic stresses. Tomato leaf curl virus (TLCV) is a devastating disease of tomato, transmitted by whitefly, ultimately results in marked reduction of tomato production. In current experiment, four tomato cultivars i.e., Reo Grande, Roma, Moneymaker and Nagina were grown under field conditions to screen against TLCV. Correlation studies revealed a positive and significant relationship among TLCV, whitefly population and environmental factors (temperature and relative humidity). Highest whitefly infestation with TLCV severity was observed on moneymaker compared to other tested cultivars. Subsequently, moneymaker was further subjected to check efficacy of botanicals (neem leaf extract and garlic clove extract), detergent and Imidacloprid against disease vector i.e., whitefly and TLCV at different concentrations under glasshouse conditions. These botanicals and detergent elucidated promising results in reducing whitefly population followed by low severity of TLCV. Whereas, Imidacloprid was most effective in reducing whitefly population up to 1.00 adult/ plant followed by neem leaf extract, garlic clove extract and detergent that reduced up to $1.33,1.67$ and 2.33 adults/ plant, respectively. It is recommended that TLCV severity could be managed by using neem leaf and garlic clove extract which ultimately reduced the whitefly population and serves as a good alternative than hazardous pesticides on food crops.

Keywords: Botanicals, garlic clove, tomato, TLCV, whitefly, pesticides.

\section{INTRODUCTION}

Tomato (Solanum lycopersicum L.) native to Tropical America is a member of nightshade family (Solanaceae). It is a rich source of minerals, essential amino acids, sugars, dietary fibers and vitamins such as vitamin B complex and vitamin C. (Glick et al., 2009). Tomato is rich with natural antioxidant -lycopene, that helps to Submitted: March 14, 2018

Revised: May 28, 2018

Accepted for Publication: June 01, 2018

* Corresponding Author:

Email: mirzaabidpp@gmail.com

(c) 2017 Pak. J. Phytopathol. All rights reserved. prevent prostate cancer (Boileau et al., 2003), and also considered beneficial for patients suffering from cardiovascular diseases (Riccioni et al., 2008). Tomato covered an area of about 5.6 thousand ha with 72.5 thousand tons production in Punjab compared to the total area of 53.4 thousand ha and 561.9 thousand tons production of Pakistan during 2013-14 (GOP, 2008).

In under developed countries, one of the most limiting factors towards modern agriculture are viral diseases (Fereres et al., 2000). Tomato served as a host for many viruses including tomato leaf curl virus (TLCV), tomato chlorosis virus (ToCV) tobacco mosaic virus (TMV), tobacco streak virus (TSV), and cucumber mosaic virus 
(CMV) etc. (Hanssen et al., 2010). TLCV is an important disease belongs to the family Geminiviridae having circular, single-stranded DNA genome virus with two incomplete icosahedral geminate particles affecting tomato production all over the world (Chakraborty, 2008; Pandey et al., 2009). TLCV is transmitted by whitefly (Bemisia tabaci Genn.) in a persistent and circulative manner as well as by grafting and not through seed, soil, sap or nematode (Uchibori et al., 2013). Whiteflies can acquire the TLCV from infected tomato fruits and transmit it into the healthier plants (Delatte et al., 2003).

Environment is an integral component of disease development without its knowledge; disease management is very difficult (Ghent et al., 2013). Disease forecasting is core area of interest for scientists to study the epidemiology and disease management. Moreover, it may help to eliminate the unnecessary use of pesticides and the risks associated with disease epidemic at field level (Dani, 2013). Many disease predictive models have been suggested by different scientists after interpreting epidemiological data including humidity, rainfall, temperature, day light etc. for facilitation of farmers and researchers (Magarey et al., 2005; Moral et al., 2012).

For good management strategies, dynamic studies of plant diseases are very much necessary (Majeed et al., 2014; Contreras-Medina et al., 2009). Present situation raises the need to adopt new ways to control insects and diseases that could be eco- friendly. A wide range of fungal, bacterial and viral diseases of economically important crops are now being managed by applying various botanicals having antimicrobial properties(Nashwa and Abo-Elyousr 2012; Chohan and Perveen 2015). Binyamin et al., (2011) applied $2 \%$ neem and garlic extracts to effectively reduce the whitefly population where as Urdbean leaf crinkle virus (ULCV) severity decreased in plants sprayed with $2 \%$ neem and akk extracts. Moreover, soft soap solutions can be used to control most of the important sucking and chewing insects including whiteflies, aphids, thrips, and small beetles (Elwell and Maas, 1995).

$$
\text { Percent Disease Index (PDI) } \%=\frac{\text { Wheeler, (1969). }}{\text { So. of leaves } x \text { Maximum examined disease scale }} \times 100
$$

Moreover, whitefly population data was recorded by randomly selecting three plants of each genotype from already
Up till now very limited work has been done to control TLCV and whitefly population using botanicals in Pakistan. Therefore, this study was designed with the objectives to enumerate the environmental factors favorable for disease development as well as whitefly population and to find out the suitable concentration of botanicals and soap solution to mitigate TLCV and whitefly population.

\section{MATERIALS AND METHODS}

Preparation of land and transplantation of nursery: The land was prepared by mixing equal amounts of farm yard manure, soil and silt prior to sowing. Seeds of four tomato varieties (moneymaker, roma, nagina and Reo Grande) were sown in the month of November covered with insect-proof net house to protect the germinating seedlings from whitefly and unfavorable environmental conditions (like fog etc.) for raising insect free nursery. The seedlings were transplanted in the field upon favorable environmental conditions. The field was prepared with row to row and plant to plant distance of 70 and $30 \mathrm{~cm}$ respectively. The recommended doses of (N: P: K) was applied during the entire study period. All cultural practices and watering were done at the time of sowing and supplied as needed. A single row of each genotype served as a replication with 10 plants/ row. The experiment was conducted during 2010-2012 while, the disease rating scale of Atta, (2006) was used in a randomized complete block design (RCBD) in triplicate.

Assessment of TLCV severity and whitefly population: TLCV severity was calculated by randomly selecting five plants of each genotype from each row and tagged. Disease severity data was recorded according to the modified disease rating scale where $0=$ No Symptoms, $1=$ mild symptoms on young leaves, $2=$ Persistent mild symptoms on margins and interveinal chlorosis, $3=$ Typical chlorosis, smalling and curling of leaves, reduction in plant growth, fruit normal $4=$ yellowing, cholorosis, shortening of internodes, curling of leaves and retarded growth, $5=$ Short internodes, stunted growth, few flowers, small fruits with uneven growth and maturity (Atta, 2006) and percent disease index (PDI) was expressed using formula of

tagged plants and this data was taken early in the morning from upper, middle and lower leaves of the selected plants. 
Management of TLCV and whitefly population: A susceptible variety "moneymaker" was grown in pots under glasshouse conditions to evaluate the efficacy of different concentrations of botanicals and detergent in comparison to commercially available insecticide where disease inoculum and whitefly population was ideal with untreated plants served as a control.

Preparation of botanicals, detergent and insecticide: Fresh, healthy leaves of neem and cloves of garlic were washed thoroughly with tap water and disinfected in $1 \%$ solution of sodium hypochlorite for 2 minutes followed by multiple rinsing in sterile distilled water to remove residues of surface disinfectant. Neem leaves were macerated with sterile distilled water in a sterilized pestle and mortar and further diluted to make final concentrations of 30, 40, 50 and $60 \mathrm{mg} / \mathrm{mL}$. Similarly, the concentrations of garlic were made by grinding and diluting garlic cloves to obtain final concentrations of 100, 150, 200 and $250 \mathrm{mg} / \mathrm{mL}$. Detergent was prepared by mixing 3, 4, 5 and $6 \mathrm{mg}$ of dish washing soap per $\mathrm{mL}$ of water. Furthermore, the insecticide Imidacloprid was also tested at four different doses viz., 4, 5, 6 and $7 \mathrm{mg} /$ $\mathrm{mL}$ as a standard of comparison (Khan et al., 2011). The spray was repeated with one week interval up to 3 weeks.

\section{Estimation of TLCV severity and whitefly population:} TLCV severity was recorded after one week while whitefly population data was noted $48 \mathrm{~h}$ before and after application of botanicals, detergent and insecticide. The experiment was conducted in a completely randomized design (CRD) in triplicate with control remained untreated.

\section{METEOROLOGICAL DATA AND STATISTICAL ANALYSIS}

Meteorological data of different environmental factors (maximum, minimum temperature and relative humidity) during the entire study period was taken from meteorological office situated near airport in Multan. Environmental data and disease severity data was analyzed by using correlation and regression analysis to find out the relationship with TLCV severity and whitefly population. Data of botanicals, detergent and insecticide was subjected to analysis of variance (ANOVA) by using statistical package Minitab 16 and Sigmaplot 12. For comparison of means, Fisher's Least Significant Difference (LSD) test was applied to separate means at 5\% probability level (Steel et al., 1997).

\section{RESULTS}

Progress of TLCV severity: Disease progress curve showed the severity of TLCV over a period of seven data recording intervals. All the varieties were susceptible to TLCV and expressed virus symptoms on leaves from mild to severe with interveinal chlorosis followed by curling of leaves and stunted growth. Moneymaker was severely affected by TLCV followed by Reo Grande, roma and nagina. Nagina variety was less affected by TLCV as compared to other three varieties and was moderately susceptible. TLCV severity was $60 \%$ during $9^{\text {th }}$ June on moneymaker followed by 56,52 and $49.6 \%$ in Reo Grande, roma and nagina respectively (Figure 1).

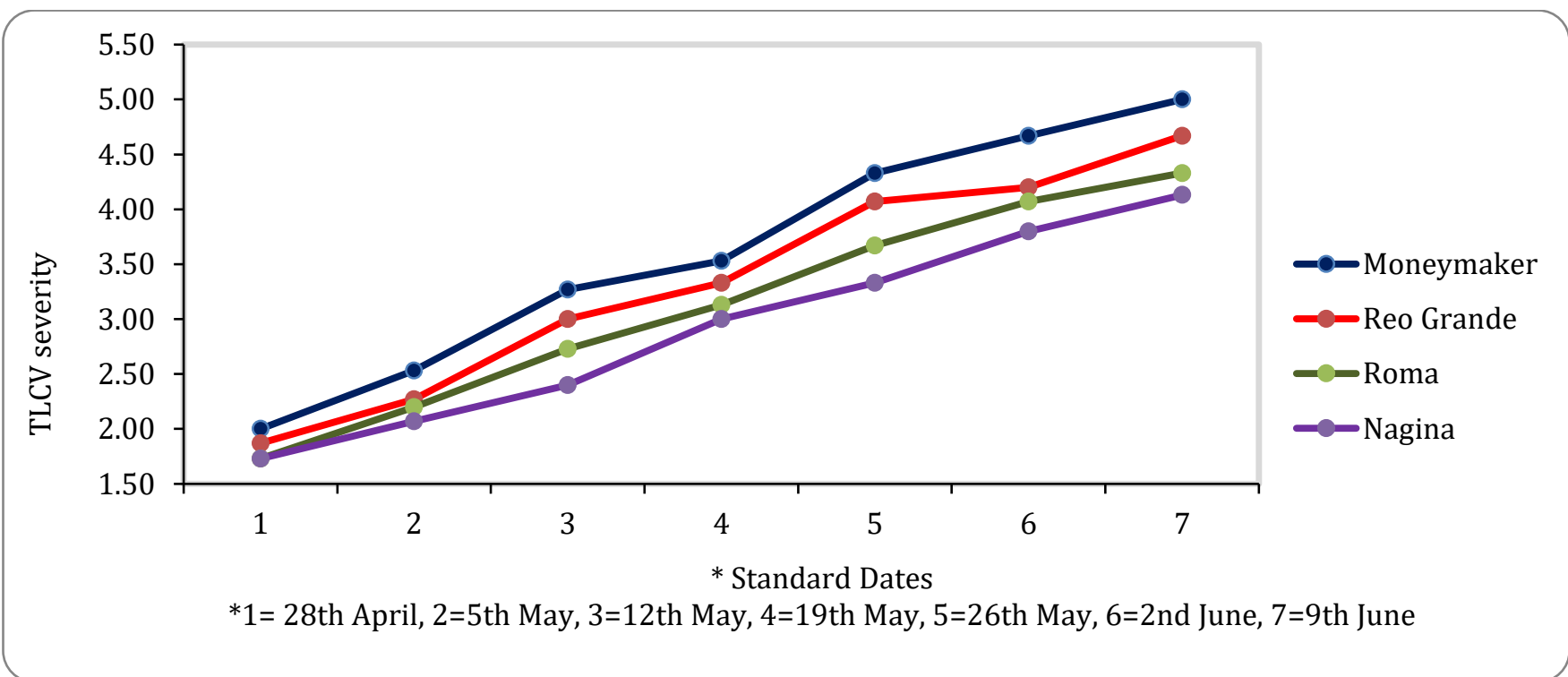

Figure 1. Disease progress curve showing severity of TLCV on four tomato varieties over time. 
Relationship of TLCV severity and environmental variables: The correlation of TLCV severity and maximum temperature was positive and statistically significant. One degree increase in maximum temperature increased the disease severity by $6.10,6.43$, 6.74 and $7.33 \%$, in nagina, roma, Reo Grande and moneymaker, respectively. There was also a positive and significant correlation between minimum temperature and TLCV severity. One degree increase in minimum temperature, increased TLCV severity by $5.54,5.15,4.77$ and $4.38 \%$ in moneymaker, Reo Grande, roma and nagina respectively and vice versa. Similar to maximum and minimum temperature, relative humidity also had positive and statistically significant relationship with TLCV severity. With one percent increase in relative humidity TLCV severity increased 2.61, 2.82, 3.04 and $3.26 \%$ for nagina, roma, Reo Grande and moneymaker, respectively (Table 1 ).

Table 1. Correlation matrix among environmental variables and TLCV severity

\begin{tabular}{|c|c|c|c|}
\hline \multirow{2}{*}{ Varieties } & \multicolumn{2}{|c|}{ Temperature $\left({ }^{\circ} \mathrm{C}\right)$} & \multirow{2}{*}{ Relative Humidity (\%) } \\
\hline & Maximum & Minimum & \\
\hline Nagina (y1) & $-219.9+6.100 \times \mathrm{x} \mathrm{r}=0.934^{*}$ & $-85.51+4.377$ x r $=0.970^{*}$ & $-56.81+2.606 x \mathrm{r}=0.977^{*}$ \\
\hline Moneymaker (y2) & $-262.8+7.328 x r=0.904^{*}$ & $-109.1+5.537$ x r=0.988* & $-71.49+3.259 x \mathrm{r}=0.984^{*}$ \\
\hline Roma (y3) & $-231.2+6.429$ x r $=0.915^{*}$ & $-93.90+4.769$ x r $=0.983^{*}$ & $-61.96+2.820 x \mathrm{r}=0.983^{*}$ \\
\hline Reo Grande (y4) & $-241.5+6.737 x r=0.892^{*}$ & $-101.9+5.154$ x r $=0.987^{*}$ & $-67.23+3.044 \times \mathrm{r}=0.986^{*}$ \\
\hline
\end{tabular}

*Significant at $5 \%$ probability level

Progress of whitefly population: Progression of whitefly population was studied during seven data recording intervals. It was observed that whitefly population fluctuated during experimental period due to varying environmental conditions. Initially whitefly population remained under economic threshold level (ETL) but it reached to maximum during $6^{\text {th }}$ and $7^{\text {th }}$ data recording interval. Moneymaker depicted the maximum average whitefly population with 5.00 nymphs/ adults/plant followed by Reo Grande, roma and nagina during $9^{\text {th }}$ June (Figure 2).

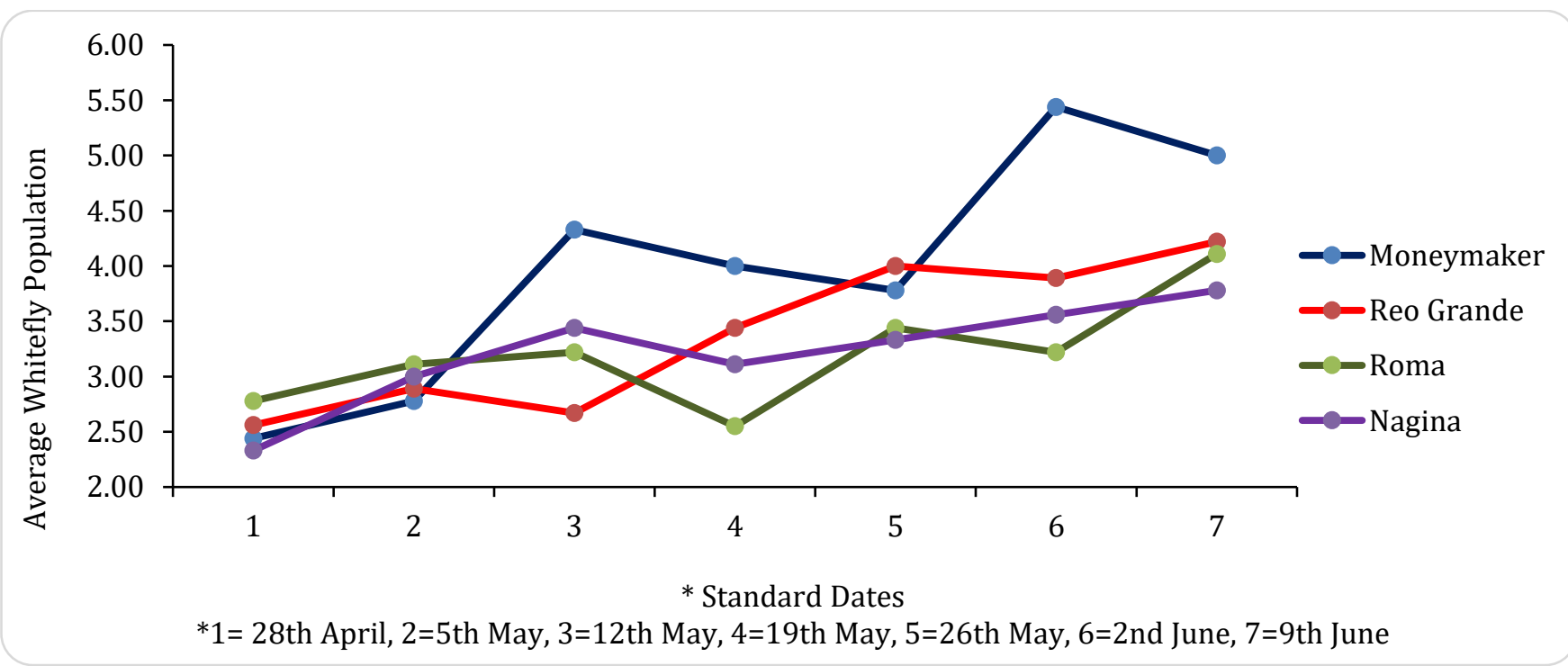

Figure 2. Progress of whitefly population on four tomato varieties over time.

Relationship of whitefly population and environmental variables: There was a positive and statistically significant correlation between whitefly population and maximum temperature. One degree increase in maximum temperature increased $0.24,0.28,0.36$ and $0.62 \%$ whitefly population in nagina, roma, Reo Grande and moneymaker respectively. Minimum temperature had also a statistically significant and positive relationship with whitefly 
population. By increasing one degree minimum temperaturewhitefly population increased $0.44,0.27,0.20$ and $0.18 \%$ on moneymaker, Reo Grande roma and nagina respectively. Whitefly population and relative humidity also showed significant correlation. One percent increase in relative humidity increased $0.11,0.26,0.11$ and $0.17 \%$ whitefly population in nagina, moneymaker, roma and Reo Grande respectively (Table 2).

Table 2. Correlation matrix among environmental variables and whitefly population

\begin{tabular}{|c|c|c|c|}
\hline \multirow{2}{*}{ Varieties } & \multicolumn{2}{|c|}{ Temperature $\left({ }^{\circ} \mathrm{C}\right)$} & \multirow{2}{*}{ Relative Humidity (\%) } \\
\hline & Maximum & Minimum & \\
\hline Nagina (y1) & $-6.73+0.240 \mathrm{x} \mathrm{r}=0.830^{*}$ & $-1.84+0.18 x$ r $=0.927^{*}$ & $-0.51+0.11 \mathrm{x} \mathrm{r}=0.902^{*}$ \\
\hline Moneymaker (y2) & $-22.05+0.62 \mathrm{xr}=0.940^{*}$ & $-8.19+0.44 x \mathrm{x}=0.964^{*}$ & $-5.13+0.26 \mathrm{x} \mathrm{r}=0.953^{*}$ \\
\hline Roma (y3) & $-8.61+0.28 \mathrm{xr}=0.934^{*}$ & $-2.25+0.20 \times \mathrm{x}=0.947^{*}$ & $-0.55+0.11 \mathrm{xr}=0.861^{*}$ \\
\hline Reo Grande (y4) & $-11.84+0.36 \mathrm{x} \mathrm{r}=0.884^{*}$ & $-4.10+0.27 \mathrm{x} \mathrm{r}=0.953^{*}$ & $-2.52+0.17 \mathrm{x} \mathrm{r}=0.994^{*}$ \\
\hline
\end{tabular}

*Significant at $5 \%$ probability level

Evaluation of botanicals and detergent against TLCV severity: Out of four varieties screened, three of them were found susceptible and one was moderately susceptible. Moneymaker variety was opted for further management experiment due to its susceptibility to TLCV and whitefly. The application of botanicals and detergent on tomato plant resulted in reduction of whitefly population and indirectly reduced the spread of virus. All the concentrations of extracts and detergent decreased TLCV severity. Neem leaf extract at 30, 40, 50 and $60 \mathrm{mg} / \mathrm{ml}$ reduced TLCV to 2.67, 2.33, 1.00 and 1.00 respectively. Garlic clove extract reduced TLCV up to $3.33,3.00,1.33$ and 1.00 at 100, 150, 200 and $250 \mathrm{mg} /$ $\mathrm{ml}$ respectively. While detergent at concentration of 3,4 , 5 and $6 \mathrm{mg} / \mathrm{ml}$ reduced TLCV up to 4.00, 3.33, 2.33 and 1.67 respectively (Table 3 ).

Table 3. Effect of different concentrations of plant extracts and detergent on TLCV severity.

\begin{tabular}{|c|c|c|}
\hline Extracts & Concentrations & TLCV severity \\
\hline \multirow{4}{*}{ Neem Leaf Extract } & $30 \mathrm{mg} / \mathrm{ml}$ & $2.67 \mathrm{~b}$ \\
\hline & $40 \mathrm{mg} / \mathrm{ml}$ & $2.33 \mathrm{~b}$ \\
\hline & $50 \mathrm{mg} / \mathrm{ml}$ & $1.00 \mathrm{c}$ \\
\hline & $60 \mathrm{mg} / \mathrm{ml}$ & $1.00 \mathrm{c}$ \\
\hline \multicolumn{2}{|c|}{ Control } & $4.67 \mathrm{a}$ \\
\hline \multicolumn{2}{|c|}{$\operatorname{LSD}(P=0.05)$} & 0.69 \\
\hline \multirow{4}{*}{ Garlic Clove Extract } & $100 \mathrm{mg} / \mathrm{ml}$ & $3.33 \mathrm{~b}$ \\
\hline & $150 \mathrm{mg} / \mathrm{ml}$ & $3.00 \mathrm{~b}$ \\
\hline & $200 \mathrm{mg} / \mathrm{ml}$ & $1.33 \mathrm{c}$ \\
\hline & $250 \mathrm{mg} / \mathrm{ml}$ & $1.00 \mathrm{c}$ \\
\hline \multicolumn{2}{|c|}{ Control } & $5.00 \mathrm{a}$ \\
\hline \multicolumn{2}{|c|}{$\operatorname{LSD}(P=0.05)$} & 0.73 \\
\hline \multirow{4}{*}{ Detergent } & $3 \mathrm{mg} / \mathrm{ml}$ & $4.00 \mathrm{ab}$ \\
\hline & $4 \mathrm{mg} / \mathrm{ml}$ & $3.33 \mathrm{~b}$ \\
\hline & $5 \mathrm{mg} / \mathrm{ml}$ & $2.33 \mathrm{c}$ \\
\hline & $6 \mathrm{mg} / \mathrm{ml}$ & $1.67 \mathrm{c}$ \\
\hline \multicolumn{2}{|c|}{ Control } & $4.67 a$ \\
\hline \multicolumn{2}{|c|}{$\operatorname{LSD}(P=0.05)$} & 0.81 \\
\hline
\end{tabular}

Means showing different letters are statistically significant at $5 \%$ probability level

Effect of different concentrations of botanicals, detergent and insecticide on whitefly population: In another experiment, the most susceptible and heavily infested variety moneymaker was grown in pots and subjected to management with different concentrations of botanicals, detergent and insecticide. All the tested treatments were applied after 1 week interval up to 3 consecutive weeks. Whitefly population was maintained 
above ETL level under glasshouse conditions to actually monitor the efficacy of concentrations of applied botanicals and insecticide with the passage of time. It was observed that all the concentrations of botanicals, detergent and imidacloprid managed the whitefly population effectively with varying degree during the study period compared to the controls. Imidacloprid ranked $1^{\text {st }}$ followed by neem leaf extract, garlic clove extract and detergent in managing whitefly population. On the contrary, neem leaf extract was found more effective even at lower concentrations compared to the insecticide. It might be due to the development of resistance in whitefly against imidacloprid. Moreover, no any phytotoxicity due to the application of these concentrations of botanicals and insecticide was observed during the study period. Conclusively, neem leaf extract at the concentration of 50 and $60 \mathrm{mg} / \mathrm{ml}$, garlic clove extract at 200 and $250 \mathrm{mg} / \mathrm{ml}$ effectively reduced the whitefly population with 3 continuous sprays with one week interval. Of them, detergent was least effective among treatments in managing whitefly population (Table 4).

Table 4. Management of whitefly population in moneymaker by the application of different concentrations of plant extracts, detergent and Imidacloprid under field condition.

\begin{tabular}{|c|c|c|c|c|c|c|c|}
\hline \multirow{2}{*}{$\begin{array}{l}\text { Extracts/ } \\
\text { Insecticide }\end{array}$} & \multirow{2}{*}{ Concentrations } & \multicolumn{2}{|c|}{ 1st Spray } & \multicolumn{2}{|c|}{ 2nd Spray } & \multicolumn{2}{|c|}{ 3rd Spray } \\
\hline & & Before & After & Before & After & Before & After \\
\hline \multirow{4}{*}{$\begin{array}{l}\text { Neem Leaf } \\
\text { Extract }\end{array}$} & $30 \mathrm{mg} / \mathrm{ml}$ & $6.33 a$ & $4.33 \mathrm{~b}$ & $5.67 \mathrm{ab}$ & $3.67 \mathrm{~b}$ & $4.67 \mathrm{a}$ & $3.67 \mathrm{~b}$ \\
\hline & $40 \mathrm{mg} / \mathrm{ml}$ & $5.67 \mathrm{a}$ & $3.67 \mathrm{bc}$ & $4.33 \mathrm{~b}$ & $3.33 \mathrm{bc}$ & $5.33 a$ & $3.00 \mathrm{bc}$ \\
\hline & $50 \mathrm{mg} / \mathrm{ml}$ & $6.00 \mathrm{a}$ & $2.67 \mathrm{~cd}$ & $3.67 \mathrm{~b}$ & $1.67 \mathrm{~cd}$ & $4.00 \mathrm{a}$ & $2.00 \mathrm{bc}$ \\
\hline & $60 \mathrm{mg} / \mathrm{ml}$ & $6.33 a$ & $2.33 \mathrm{~d}$ & $5.33 \mathrm{ab}$ & $1.33 \mathrm{~d}$ & $4.67 \mathrm{a}$ & $1.33 \mathrm{c}$ \\
\hline \multicolumn{2}{|c|}{ Control } & $7.33 \mathrm{a}$ & $8.67 a$ & $7.00 \mathrm{a}$ & $5.67 a$ & $5.67 a$ & $6.67 \mathrm{a}$ \\
\hline \multicolumn{2}{|c|}{$\operatorname{LSD}(P=0.05)$} & 1.89 & 1.03 & 2.05 & 1.68 & 2.12 & 1.82 \\
\hline \multirow{4}{*}{ Detergent } & $3 \mathrm{mg} / \mathrm{ml}$ & $6.00 \mathrm{ab}$ & $5.33 \mathrm{~b}$ & $5.33 a$ & $4.67 \mathrm{~b}$ & $4.00 \mathrm{~b}$ & $3.33 \mathrm{bc}$ \\
\hline & $4 \mathrm{mg} / \mathrm{ml}$ & $5.33 \mathrm{~b}$ & $4.67 \mathrm{~b}$ & $4.33 \mathrm{a}$ & $4.00 \mathrm{bc}$ & $5.67 \mathrm{a}$ & $4.67 \mathrm{ab}$ \\
\hline & $5 \mathrm{mg} / \mathrm{ml}$ & $6.67 \mathrm{ab}$ & $3.67 \mathrm{~b}$ & $5.67 \mathrm{a}$ & $3.33 \mathrm{bc}$ & $4.33 \mathrm{ab}$ & $2.67 \mathrm{c}$ \\
\hline & $6 \mathrm{mg} / \mathrm{ml}$ & $5.67 \mathrm{~b}$ & $3.33 \mathrm{~b}$ & $5.00 \mathrm{a}$ & $3.00 \mathrm{c}$ & $4.00 \mathrm{~b}$ & $2.33 c$ \\
\hline \multicolumn{2}{|c|}{ Control } & $7.67 a$ & $9.00 a$ & $6.33 a$ & $6.67 \mathrm{a}$ & $5.67 \mathrm{a}$ & $5.00 \mathrm{a}$ \\
\hline \multicolumn{2}{|c|}{$\operatorname{LSD}(P=0.05)$} & 1.99 & 2.29 & 2.32 & 1.56 & 1.56 & 1.67 \\
\hline \multirow{4}{*}{$\begin{array}{c}\text { Garlic Clove } \\
\text { Extract }\end{array}$} & $100 \mathrm{mg} / \mathrm{ml}$ & $6.67 \mathrm{ab}$ & $5.33 \mathrm{ab}$ & $6.00 \mathrm{ab}$ & $4.33 \mathrm{ab}$ & $5.33 \mathrm{a}$ & $4.00 \mathrm{~b}$ \\
\hline & $150 \mathrm{mg} / \mathrm{ml}$ & $6.33 \mathrm{~b}$ & $4.00 \mathrm{bc}$ & $5.33 \mathrm{ab}$ & $3.67 \mathrm{bc}$ & $6.00 \mathrm{a}$ & $4.00 \mathrm{~b}$ \\
\hline & $200 \mathrm{mg} / \mathrm{ml}$ & $5.00 \mathrm{~b}$ & $3.33 \mathrm{bc}$ & $4.00 \mathrm{~b}$ & $2.67 \mathrm{~cd}$ & $4.67 \mathrm{a}$ & $2.33 \mathrm{bc}$ \\
\hline & $250 \mathrm{mg} / \mathrm{ml}$ & $5.33 \mathrm{~b}$ & $3.00 \mathrm{c}$ & $4.67 \mathrm{ab}$ & $2.33 \mathrm{~d}$ & $5.33 a$ & $1.67 \mathrm{c}$ \\
\hline \multicolumn{2}{|c|}{ Control } & $8.33 a$ & $6.67 a$ & $6.33 a$ & $5.00 \mathrm{a}$ & $5.00 \mathrm{a}$ & $7.33 a$ \\
\hline \multicolumn{2}{|c|}{$\operatorname{LSD}(P=0.05)$} & 1.95 & 2.05 & 2.29 & 1.24 & 1.56 & 2.09 \\
\hline \multirow{4}{*}{ Imidacloprid } & $4 \mathrm{mg} / \mathrm{ml}$ & $8.33 a$ & $4.67 \mathrm{ab}$ & $7.67 a$ & $4.00 \mathrm{~b}$ & $6.33 \mathrm{ab}$ & $3.33 b$ \\
\hline & $5 \mathrm{mg} / \mathrm{ml}$ & $6.67 \mathrm{ab}$ & $4.00 \mathrm{bc}$ & $6.00 \mathrm{ab}$ & $3.00 \mathrm{~b}$ & $5.00 \mathrm{bc}$ & $2.67 \mathrm{~b}$ \\
\hline & $6 \mathrm{mg} / \mathrm{ml}$ & 7.33ab & $2.33 c$ & $5.67 \mathrm{ab}$ & $1.67 \mathrm{c}$ & $4.67 \mathrm{c}$ & $2.00 \mathrm{bc}$ \\
\hline & $7 \mathrm{mg} / \mathrm{ml}$ & $6.00 \mathrm{~b}$ & $2.00 c$ & $5.00 \mathrm{~b}$ & $1.00 \mathrm{c}$ & $4.33 \mathrm{c}$ & $1.00 \mathrm{c}$ \\
\hline \multirow{2}{*}{\multicolumn{2}{|c|}{ Control }} & 7.67ab & $6.67 \mathrm{a}$ & $7.00 \mathrm{ab}$ & $8.33 a$ & $6.67 \mathrm{a}$ & $7.67 \mathrm{a}$ \\
\hline & & 2.05 & 2.30 & 2.66 & 1.33 & 1.49 & 1.41 \\
\hline
\end{tabular}

Means showing different letters are statistically significant at 5\% probability level

\section{DISCUSSION}

In the present study, moneymaker, roma, Reo Grande and nagina cultivars of tomato were checked for their response against TLCV under field conditions. Moneymaker was the most susceptible variety heavily infested by the vector whitefly that belongs to order Homoptera. Plant viruses are vectored by arthropods especially the members of Homoptera (Nault, 1997). Extent of disease depends upon vector population, plant resistance to vectors, viruses and its transmission process. Whereas, morphology, physiology and resistance of host to vectors and viruses including their life cycles, abundance, reservoirs and inoculums can be affected variedly due to varying environmental conditions(Jones, 2014). It was also observed that with an increase in temperature there was a positive correlation not only with whitefly population but also with TLCV severity. 
Fluctuating temperatures vary the incidence of viral diseases (Glasa et al., 2003).

According to Saikia and Muniyappa, (1989) TYLCV incidence can be reduced by growing plants under covering of fine net. TLCV incidence reached to $100 \%$ by fourth and fifth week of transplanting on tomato nursery raised in the absence of nylon net covering (Anithacherian, 1998). Moreover, appearance and spread of disease will be greater if the vector population was more in the first month of transplanting. Incidence of TYLCV was less (17-53\%) from July to November but range up to $100 \%$ from Feb- May. About $90-100 \%$ of the plants were diseased in the area where tomato crop was sown between the end of February and the end of May (Rashid et al., 2008).

Population dynamics is influenced by temperature which helps to develop population models. The spread of TYLCV was significantly correlated with increased whitefly population. In present investigations, whitefly population variedly increased from April to June and these results are supported by the previous studies where whitefly population was recorded maximum in March to June resulting in more incidence of disease (Bonato et al., 2007; Garrett et al., 2006; Rahman et al., 2006; Rashid et al., 2008). Incidence of TLCV was directly proportional to the vector population, B. tabaci (Aboul-Ata et al., 2000). Developmental processes and activities of whitefly are favored by increasing temperature and relative humidity. Whitefly population and disease progress was rapid during hot kharif season i.e. February-May (Saikia and Muniyappa 1989), and TLCV incidence decreased with increasing relative humidity (Aktar et al., 2008; Kaushik, 2012; Zeshan et al., 2016). Our results are in agreement with the findings of these researchers.

There was a positive relationship between maximum and minimum temperature with whitefly population. TLCV severity increased with increasing relative humidity as these conditions favors the whitefly infestation which is a vector of this virus. Previous studies are also in agreement with the findings where TLCV incidence was directly proportional to relative humidity (Haque, 2002; Paul, 2002; Rai et al., 2001; Sultana, 2001). Maximum whitefly infestation at high temperature and low relative humidity was studied on okra (Ali et al., 2005).
Although genetic resistance is the only way to control viral diseases but high temperature resulted in inhibition of activities of different resistance genes and ultimately enhance disease incidence (de Jong et al., 2002). But in present study, out of four varieties none of the cultivar showed resistance against TLCV and whitefly infestation. Insecticidal control of vector is often ineffective and frequent use of synthetic chemical insecticides results in acute and chronic toxicity to growers and consumers, contamination of groundwater and resistance development in specific insect pests (Perring et al., 1999; Glover-Amengor and Tetteh 2008). To combat this problem botanicals and detergent were used to minimize the hazards of environmental pollution associated with insecticide sprays. Botanicals are natural chemicals produced by plants effective to control insect pest population (Weaver and Sumbramanyam 2000), readily breakdown as compared to synthetic chemicals and are ecofriendly in nature. Neem products being nontoxic to human, warm-blooded animals and beneficial insects can be used to control insect pests of tomato crop (Ogemah, 2003). Similarly,Madhusudhan et al., (2011) reported that botanicals of bougainvillea, garlic and neem have the ability to reduce the infection and proliferation of plant viruses. Effects of insecticidal soap (detergents), mineral oils and neem products containing azadirachtin on whitefly population and natural enemies were studied and it was concluded that they were toxic to whitefly nymphs(Liu and Stansly 1995a; Liu and Stansly 1995b; Schuster and Stansly 2000). Detergents when applied at $0.5 \%$ concentration or more are helpful to control whitefly population (Vavrina et al., 1995). The results of present study are corroborated with the outcome of these scientists.

\section{CONCLUSION}

From the above discussion, it can be concluded that whitefly is the major cause of spreading TLCV under field conditions. Epidemiological studies revealed that TLCV disease increased with the increase in temperature and humidity which is positively correlated with whitefly population. The use of plant extracts to control the whitefly population thus reducing the tomato leaf curl virus is suggested. The use of plant extracts and detergent is a cheaper and safer mean to control the vector and virus simultaneously compared to the use of insecticides, the latter is hazardous to human health and environment.

\section{ACKNOWLEDGMENTS}


We are very thankful to Vegetable Section, Ayub Agriculture Research Institute (AARI), Faisalabad for providing seeds of tomato.

\section{REFERENCES}

Aboul-Ata, A. E., M. A. E. Awad, S. Abdel-Aziz, D. Peters, H. Megahed and A. Sabik. 2000. Epidemiology of tomato yellow leaf curl begomovirus in the Fayium area, Egypt. EPPO Bulletin, 30: 297-300.

Aktar, M., M. Akhter and A. Akanda. 2008. Impact of insecticides and organic oil spray on the growth and yield of tomato under TYLCV infected condition. Bangladesh Res. Publ. J, 1: 199-205.

Ali, S., M. Khan, A. Habib, S. Rasheed and Y. Iftikhar. 2005. Correlation of environmental conditions with okra yellow vein mosaic virus and Bemisia tabaci population density. International Journal of Agriculture and Biology, 7: 142-144.

Anithacherian, K. 1998. Management of tomato leaf curl virus in tomato through the control of its whitefly vector, Bemisia tabaci Genn. by entamopathogenic fungi. UAS Bangalore.

Atta, S. 2006. Impact of epidemiological factors on tomato leaf curl virus (TLCV) development and its management. Department of Plant Pathology. University of Agriculture, Faisalabad.

Binyamin, R., M. A. Khan, N. Ahmad and A. Safdar. 2011. Relationship of epidemiological factors with urdbean leaf crinkle virus disease and its management using plant extracts. International Journal of Agriculture and Biology, 13.

Boileau, T. W. M. 2003. Prostate Carcinogenesis in Nmethyl-N-nitrosourea (NMU)-TestosteroneTreated Rats Fed Tomato Powder, Lycopene, or Energy-Restricted Diets. Cancer Spectrum Knowledge Environment, 95: 1578-1586.

Bonato, O., A. Lurette, C. Vidal and J. Fargues. 2007. Modelling temperature-dependent bionomics of Bemisia tabaci (Q-biotype). Physiological Entomology, 32: 50-55.

Chakraborty, K. 2012. Incidence and abundance of whitefly, Bemisia tabaci, Gen. and the occurrence of tomato yellow leaf curl virus disease (TYLCV) in relation to the climatic conditions of Alipurduar, Jalpaiguri, West Bengal, India. Journal of Entomological Research, 36: 35-40.

Chakraborty, S. 2008. Tomato Leaf Curl Viruses from India. Encyclopedia of Virology. Elsevier, pp. 124133.
Chohan, S. and R. Perveen. 2015. Phytochemical Analysis and Antifungal Efficacy of Rhizome Extracts of various plants against Fusarium Wilt and Root Rot of Tomato. International Journal of Agriculture and Biology, 17: 1193-1199.

Contreras-Medina, L., I. Torres-Pacheco, R. GuevaraGonzález, R. Romero-Troncoso, I. Terol-Villalobos and R. Osornio-Rios. 2009. Mathematical modeling tendencies in plant pathology. African Journal of Biotechnology, 8: 7399-7408.

de Jong, C. F., F. L. W. Takken, X. Cai, P. J. G. M. de Wit and M. H. A. J. Joosten. 2002. Attenuation of Cf-Mediated Defense Responses at Elevated Temperatures Correlates with a Decrease in Elicitor-Binding Sites. Molecular Plant-Microbe Interactions, 15: 10401049.

Delatte, H., A. Dalmon, D. Rist, I. Soustrade, G. Wuster, J. M. Lett, R. W. Goldbach, M. Peterschmitt and B. Reynaud. 2003. Tomato yellow leaf curl virusCan Be Acquired and Transmitted by Bemisia tabaci (Gennadius) from Tomato Fruit. Plant Disease, 87: 1297-1300.

Elwell, H. and A. Maas. 1995. Natural pest and disease control. Natural Farming Network Zimbabwe.

Fereres, A., J. Thresh and M. Irwin. 2000. Special Issue: Plant Virus Epidemiology: challenges for the twenty-first century, Almeria, Spain, 11-16 April 1999. Virus Research, 71.

Garrett, K. A., S. P. Dendy, E. E. Frank, M. N. Rouse and S. E. Travers. 2006. Climate Change Effects on Plant Disease: Genomes to Ecosystems. Annual Review of Phytopathology, 44: 489-509.

Ghent, D. H., W. F. Mahaffee, N. McRoberts and W. F. Pfender. 2013. The Use and Role of Predictive Systems in Disease Management. Annual Review of Phytopathology, 51: 267-289.

Glasa, M., G. Labonne and J. Quiot. 2003. Effect of temperature on Plum pox virus infection. Acta virologica, 47: 49-52.

Glick, E., Y. Levy and Y. Gafni. 2009. The viral etiology of tomato yellow leaf curl disease - a review. Plant Protection Science, 45: 81-97.

Glover-Amengor, M. and F. M. Tetteh. 2008. Effect of pesticide application rate on yield of vegetables and soil microbial communities. West African Journal of Applied Ecology, 12.

GOP. 2008. Agricultural Statistics of Pakistan, Economic Wing Ministry of Food Agriculture and Livestock. 
Islamabad Pakistan.

Hanssen, I. M., M. Lapidot and B. P. H. J. Thomma. 2010. Emerging Viral Diseases of Tomato Crops. Molecular Plant-Microbe Interactions, 23: 539-548.

Haque, M. M. 2002. Effect of conditions of seedling raising and insecticide spray on prevalence of TYLCV and its impact on growth and yield of tomato.

Jones, R. A. C. 2014. Plant virus ecology and epidemiology: historical perspectives, recent progress and future prospects. Annals of Applied Biology, 164: 320-347.

Liu, T.-X. and P. A. Stansly. 1995a. Toxicity and repellency of some biorational insecticides to Bemisia argentifolii on tomato plants. Entomologia Experimentalis et Applicata, 74: 137-143.

Liu, T.-X. and P. A. Stansly. 1995b. Toxicity of Biorational Insecticides to Bemisia argentifolii (Homoptera: Aleyrodidae) on Tomato Leaves. Journal of Economic Entomology, 88: 564-568.

Madhusudhan, K. N., G. Vinayarani, S. A. Deepak, S. R. Niranjana, H. S. Prakash, G. P. Singh, A. K. Sinha and B. C. Prasad. 2011. Antiviral Activity of Plant Extracts and other Inducers against Tobamoviruses Infection in Bell Pepper and Tomato Plants. International Journal of Plant Pathology, 2: 35-42.

Magarey, R. D., T. B. Sutton and C. L. Thayer. 2005. A Simple Generic Infection Model for Foliar Fungal Plant Pathogens. Phytopathology, 95: 92-100.

Majeed, A., Z. Chaudhry and Z. Muhammad. 2014. Variation in the aggressiveness of Phytophthora infestans pathotypes collected from different potato fields of Khyber Pakhtunkhwa (Pakistan). Int. J. Agric. Biol, 16: 807-812.

Moral, J., J. Jurado-Bello, M. I. Sánchez, R. de Oliveira and A. Trapero. 2012. Effect of Temperature, Wetness Duration, and Planting Density on Olive Anthracnose Caused by Colletotrichum spp. Phytopathology, 102: 974-981.

Nashwa, S. M. A. and K. A. M. Abo-Elyousr. 2012. Evaluation of various plant extracts against the early blight disease of tomato plants under greenhouse and field conditions. Plant Protection Science, 48: 74-79.

Nault, L. R. 1997. Arthropod Transmission of Plant Viruses: a New Synthesis. Annals of the Entomological Society of America, 90: 521-541.

Ogemah, V. K. 2003. Influence of Derivatives of Neem Tree (Azadirachta Indica A. JUSS.) on the Biology and Behaviour of Prostephanus Truncatus
(HORN)(Coleoptera: Bostrichidae) and Its Predator, Teretrius Nigrescens (Lewis)(Coleoptera: Histeridae). Dissertation. de.

Pandey, P., N. R. Choudhury and S. K. Mukherjee. 2009. A geminiviral amplicon (VA) derived from Tomato leaf curl virus (ToLCV) can replicate in a wide variety of plant species and also acts as a VIGS vector. Virology Journal, 6: 152.

Paul, S. 2002. Management of TYLCV in respect to growth and yield of tomato using net house grown seedlings and insecticidal spray. Unpublished [MS Thesis], Department of Plant Pathology, BSMRAU, Gazipur: 107.

Perring, T. M., N. M. Gruenhagen and C. A. Farrar. 1999. Management of Plant Viral Diseases Through Chemical Control Of Insect Vectors. Annual Review of Entomology, 44: 457-481.

Rahman, A., A. M. Akanda and A. K. M. A. Alam. 2006. Relationship of Whitefly Population Build up with the Spread of TYLCV on Eight Tomato Varieties. Journal of Agriculture \& Rural Development, 4 (1\&2):67-74.

Rai, N., R. Pathak and T. Tirkey. 2001. Studies on relationship between environmental conditions on tomato leaf curl virus (TLCV) incidence. II. Screening of tomato genotypes and their stability against TLCV. Progressive Horticulture, 33: 184189.

Rashid, M., I. Hossain, A. Hannan, S. Uddin and M. Hossain. 2008. Effect of different dates of planting time on prevalence of Tomato yellow leaf curl virus and whitefly of tomato. J. Soil Nature, 2: 1-6.

Riccioni, G., Mancini, B. Ilio, E.D.I. Bucciarelli, T. Orazio, N.D. . 2008. Protective effect of lycopene in cardiovascular disease. . Eurpean Rev. Med. Pharmacol. Sci. , 12: 183-190.

Saikia, A. and V. Muniyappa. 1989. Epidemiology and control of tomato leaf curl virus in Southern India. Trop. Agric, 66: 350-354.

Schuster, D. J. and P. A. Stansly. 2000. Response of two lacewing species to biorational and broadspectrum insecticides. Phytoparasitica, 28: 297304.

Shtienberg, D. 2013. Will Decision-Support Systems Be Widely Used for the Management of Plant Diseases? Annual Review of Phytopathology, 51: 1-16.

Steel, R. G. and J. H. Torrie. 1986. Principles and procedures of statistics: a biometrical approach. 
McGraw-Hill.

Sultana, N. 2001. An investigation to some aspects of TYLCV and TPVV infecting tomato. Unpublished [MS Thesis], Department of Plant Pathology, BSMRAU, Gazipur: 90.

Uchibori, M., A. Hirata, M. Suzuki and M. Ugaki. 2013. Tomato yellow leaf curl virus accumulates in vesicle-like structures in descending and ascending midgut epithelial cells of the vector whitefly, Bemisia tabaci, but not in those of nonvector whitefly Trialeurodes vaporariorum. Journal of General Plant Pathology, 79: 115-122.

Vavrina, C., P. Stansly and T. Liu. 1995. Household detergent on tomato: phytotoxicity and toxicity to silverleaf whitefly. HortScience, 30: 1406-1409.

Weaver, D. K. and B. Subramanyam. 2000. Botanicals. Alternatives to Pesticides in Stored-Product IPM. Springer US, pp. 303-320.

Wheeler, B. E. J. 1969. An introduction to plant diseases. The English Language Book Society And John Wiley And Sons Limited; London.

Zeshan, M. A., M. A. Khan, S. Ali, N. Ahmed and M. Arshad. 2016. Epidemiological Studies of Tomato Leaf Curl Virus Disease Based upon Environmental Variables. International Journal of Agriculture and Biology, 18: 1061-1066. 